\title{
Linx
}

Revue des linguistes de l'université Paris X Nanterre

$79 \mid 2019$

Enseigner et apprendre à interagir en langue étrangère : réflexions linguistiques et didactiques

\section{Interaction management in academic speaking}

La gestion de l'interaction dans les productions orales universitaires

Michael McCARTHY and Jeanne McCARTEN

\section{(2) OpenEdition \\ Journals}

Electronic version

URL: http://journals.openedition.org/linx/3611

DOI: $10.4000 /$ linx.3611

ISSN: 2118-9692

Publisher

Presses universitaires de Paris Nanterre

\section{Electronic reference}

Michael McCARTHY and Jeanne McCARTEN, « Interaction management in academic speaking », Linx [Online], 79 | 2019, document 5, Online since 30 December 2019, connection on 07 April 2020. URL

http://journals.openedition.org/linx/3611 ; DOI : https://doi.org/10.4000/linx.3611

This text was automatically generated on 7 April 2020.

Département de Sciences du langage, Université Paris Ouest 


\title{
Interaction management in academic speaking
}

\author{
La gestion de l'interaction dans les productions orales universitaires
}

Michael McCARTHY and Jeanne McCARTEN

\section{Introduction}

1 Recent developments in the study of spoken language have made possible fundamental insights into the nature of interaction, thanks to the work of discourse analysts, conversation analysts and corpus linguists. In the case of English, the language under scrutiny in this article, studies have illuminated interactional practices in everyday, casual conversation and other types of non-institutional talk. Taken together, insights into informal talk, especially social conversation, provide a benchmark for comparisons with other, more specialised contexts of use, such as business English or, in the present case, academic English.

2 Academic English has a long history of study, especially in the description of academic genres, though such studies were, in the past, mostly concerned with written texts and written academic genres (see Biber 2006: chapter 1 for a discussion, see also Bhatia 2002). Side by side with the written studies, there has been a long tradition of investigating academic lecture monologue (Coulthard and Montgomery 1981, Chaudron and Richards 1986, Strodt-Lopez 1991, Young 1994, Thompson 2003, Fortanet 2004, Bamford 2005, Nesi and Basturkmen 2006, Lee and Subtirelu 2015). Although academic lectures are single-voiced, monologue can be a misleading term, and much of the research has shown the importance of interaction with the audience, a point we return to later.

3 For a long time, relatively less research was carried out into other types of spoken academic interaction such as classes, seminars, oral presentations and one-to-one tutorial/advisory sessions. However, since the turn of the millennium, ever-increasing attention has been paid to speaking in these academic contexts, including research emanating from the MICASE corpus project (Swales \& Malczewski 2001, Poos and 
Simpson 2002, Mauranen 2004) and research into the T2K-SWAL corpus by Biber and his associates (Biber 2006), along with studies by Benwell and Stokoe (2002), Csomay (2007), Evison (2013a and b), Young 2013, Buttery, Carter and McCarthy (2015), Lee and Subtirelu (2015) and Rendle-Short (2016), among others.

It is a widely held practice among conversation analysts and corpus linguists to measure the characteristics of special varieties of spoken English (such as academic speaking) by using everyday social conversation as a benchmark (Drew and Heritage 1992). The special variety is characterised in terms of similarities with and differences from selected features of conversational interaction. One of the reasons why this is a particularly useful practice in the present context is that, as Buttery et al. (2015) mention, present-day public discourses often adapt features of banal, everyday conversation to achieve their various goals, a process that has been termed the conversationalization of discourse, (Fairclough 1994: 253). An example of this is O'Keeffe's (2006) study of radio phone-in talk, where hosts manage the interaction with callers in a way that brings callers and other listeners into a world where they feel they are engaged in or eavesdropping on a real conversation. Buttery et al. show how various high-frequency features of social conversation (e.g. personal pronouns I and you and lexical items such as know and like) are widely distributed across different academic events (lectures, seminars, supervisions), albeit they may vary within events given the same timetabling-title within individual institutions; for example, an event timetabled as a lecture may vary greatly in style of delivery from individual to individual lecturer. This suggests that to study academic speaking in a compartmentalised way based on timetable-labelled events may lead us to miss commonalities across such events which can be exploited in pedagogy. In this article, we attempt to avoid such compartmentalising and look for what different spoken academic events have in common and what they borrow from casual conversation. We define casual conversation as informal social exchanges which have no agenda or pre-determined topics, goals or duration, involving speakers who may display a range of interpersonal relations (intimates, friends, colleagues, strangers, etc.). Academic discourse, on the other hand, is characterised by institutional agendas, topics and goals and is normally time-constrained.

In this article, we examine four features of everyday social conversation which have been investigated in general spoken corpora and which are also present in spoken academic data: (a) the use of discourse markers, (b) vague category markers, (c) response tokens and (d) overlapping in part with the other three, high frequency chunks. Although these four phenomena in no way represent an exhaustive list of spoken discourse features, they correspond to and exemplify four major features of interaction: (a) actions routinely carried out by speakers to organise their own, individual contributions to the discourse and to exert control over the discourse as a whole, (b) the taking into account of the listener by projecting aspects of shared and non-shared knowledge, (c) showing oneself to be an active and engaged listener and (d) the exploitation of a repertoire of chunks and their associated pragmatic functions. We take each feature in turn and discuss its role in social conversation and in academic discourse, then discuss whether and how such features can be taught in order to prepare students for academic life in an L2 environment.

6 The data we use in the present article are taken from various sources. For benchmarking purposes and for specific academic extracts, we use CANCODE 
(Cambridge and Nottingham Corpus of Discourse in English), a five-million-word corpus of everyday spoken English which has sub-components of social conversation (one million words) and a smaller component of speaking in academic contexts $(460,000$ words); for full details of the corpus and its composition, see McCarthy (1998). The corpus is the copyright of Cambridge University Press, from whom permission must be obtained for its use. We also use data from the British Academic Spoken English (BASE) corpus, a 1.6 million-word collection of lecture and seminar data recorded under four broad disciplinary headings. BASE was developed at the UK Universities of Warwick and Reading under the directorship of Hilary Nesi (Warwick) and Paul Thompson (Reading). Corpus development was assisted by funding from the Universities of Warwick and Reading, BALEAP, EURALEX, the British Academy and the Arts and Humanities Research Board. In addition, we refer to data from the Michigan Corpus of Spoken Academic English (MICASE), which is a collection of about 1.8 million words of data from a range of academic contexts (lectures, classroom discussions, lab sections, seminars, advising sessions, etc.) from various locations across the University of Michigan. Additionally, for comparison purposes, we use the one-million-word written academic sub-corpus of the British National Corpus Baby Edition (BNCB), a collection of texts from academic books and journals. Finally, most recently, our research has benefitted from access to the Oxford Phrasal Academic Lexicon (OPAL), a set of wordand phrase-lists which includes spoken lists of words and chunks generated from a subset of the BASE corpus. BASE, MICASE, BNCB and OPAL are all freely accessible online.

\section{Corpora and core features of everyday conversational interaction}

7 The availability of spoken corpora, especially those containing unscripted, informal conversation, has revolutionised the study of conversational interaction. Corpusinformed applied linguistic and pedagogically-oriented reference works and individual studies such as Stenström (1994) Carter and McCarthy (1995), Carter and McCarthy (1997), McCarthy (1998), Biber et al (1999), Carter and McCarthy (2006), Rühlemann (2007), Beeching (2016) have described the language of social interaction, building on the knowledge base established by earlier conversational analysts (Sacks et al. 1974, Goffman 1981, Atkinson and Heritage 1984, Hutchby \& Wooffitt 1988 among others) and augmenting their work by exploiting the power of large-scale data, where conversation analysts tended to work with individual transcripts. What has also been underlined by the evidence of corpus studies is the highly context-sensitive nature of spoken interaction. Face-to-face interaction in social conversation is different from interaction with business colleagues or clients, and different again in academic contexts between tutors and students and among students engaged in academic work. These differences demand of users a type of competence over and above knowledge of the language system, a competence which we refer to as interactional competence. Young (2013) outlines key elements of interactional competence, which include:

"knowledge of rhetorical scripts, a knowledge of register - that is certain lexis and syntactic patterns specific to the practice, a knowledge of how to take turns-at-talk, a knowledge of topical organization, a knowledge of the appropriate participation framework, and a knowledge of the means for signalling boundaries between practices and transitions within the practice itself." (p. 18) 

(2018). The 'rhetorical scripts' and registers which concern us here are the various contexts of academic speaking. How to discover these in corpora is a matter first of statistical operations, followed by close examination of extended stretches of discourse to adduce functions in context of the formal features under investigation. The software tools employed to identify the core features of everyday interaction in conversation basically involve counting of frequently recurring items and patterns; however, this can be done in different ways for different purposes. We look at these in turn. typically appear as the headword in a dictionary entry), constitute the most obvious and immediate way of identifying core items within a particular corpus and they are a useful starting point in any corpus investigation; see for example, Guillot's (2002) discussion of the distribution of word-classes in frequency lists. At one end they reveal the most frequent words in any given corpus, words which must be part of any language teaching syllabus and, conversely, they can provide information on lower frequency items which may be less important and given lower priority. Studies have shown considerable variation in estimates of how many words learners of English need to know in order to comprehend spoken and written texts (anything from 2-3,000 to 8-9,000 words); a recent re-examination of such studies may be found in Schmitt et al. (2017). There are also common-sense, practical factors which may lead individual syllabuses and the teachers who deliver them to prioritise certain words of low frequency.

11 We refer first off to a one-million-word social and intimate conversational sub-corpus of the five-million-word CANCODE spoken English corpus (see above). The most frequent single word items in the sub-corpus include, as one might expect, grammatical words (articles, prepositions, conjunctions, pronouns). The personal pronouns I and you occur within the top five most frequent forms, with you about $20 \%$ less frequent than I. I and you underscore the interpersonal back-and-forth processes of conversation. Within the top 60 items are the lexical verbs know and think, owing to their frequent use in the expressions you know and I think; hesitation markers er and $\mathrm{mm}$, indicating the real-time ongoing nature of conversation which requires thinking time; the exclamation oh; the adverb just, which functions largely as a hedge; the discourse markers well, which mostly occurs at the beginning of speaker turns in responses, and right, as well as the word all, which frequently combines with right in all right, functioning as both a discourse marker and as a response token (see below). High in the list also is the informal response token Yeah.

12 A comparison between the CANCODE sub-corpus and the BASE corpus shows a great degree of overlap in terms of the main grammatical items, though raw frequencies tell us little of who actually uses the items in question. In the BASE academic data, $I$ and you have now reversed ranks, with you being $60 \%$ more frequent than I. The top 60 words include other familiar items from the social conversational data such as well, right, okay, know and think. We shall return to the status of I and you later.

13 From a language pedagogy point of view, wordlists can also assist in identifying how many words learners need to understand texts (whether spoken or written). Adolphs and Schmitt $(2003,2004)$ working with CANCODE and British National Corpus (BNC) 
spoken data show that around 5,000 word-forms make up about 96 per cent of a typical, everyday spoken text. This figure of 5,000 forms is a useful target for learners wishing to participate somewhat confidently in general conversation. In terms of academic spoken language, however, it can be regarded as a minimum for those seeking to use a language in more specialised contexts such as lectures, seminars, and so on. As Adolphs and Schmitt (2004) find, the extent of text coverage by a given number of words shows some degree of variation depending on the context, with pedagogic discourse in academic and training contexts requiring greater vocabulary knowledge. Dang and Webb (2014) also show that learners need more words to be able to understand academic spoken English than general conversation; this would align with Young's (2013) notion of knowledge of rhetorical scripts and registers as a feature of interactional competence. In this regard, a word list such as the single-word spoken list of the OPAL resource is an extremely useful repository as a baseline for learning, especially as the words in the list can be isolated into sub-groups for progressive study from most frequent to less frequent.

from the ability of corpus software to identify strings of frequently recurring multiword items, typically of between two and six or seven words long. These strings are variously referred to in the literature as 'chunks', 'clusters', 'lexical bundles', 'lexical phrases', 'multi-word units', or 'formulaic sequences' (Nattinger and DeCarrico 1992, Biber et al. 1999, Wray 2000, Schmitt 2004, Carter and McCarthy 2006: 828-837, O'Keeffe, McCarthy and Carter 2007, Biber 2009). Typical, frequent examples of chunks in spoken data are you know, I don't know, stuff like that, at the end of the day, though not all chunks in the frequency lists are as neat as these examples, which have a unitary meaning and can be recognised as independent, freestanding expressions. Many chunks consist of items with no apparent discrete, unified meaning, such as and then you, going to have, I want to be able to, which often function as frames for longer stretches of discourse; others include items which belong to longer chunks (e.g. if you see and see what I in if you see what I mean).

McCarten (2010) points out that many such chunks, including I mean, I don't know and or something, have a higher frequency than many single words which would be considered as basic core vocabulary for any elementary course book syllabus, including some words for basic colours (e.g. black), numbers (e.g. six) and everyday nouns (e.g. woman). The knowledge and mastery of chunks, then, would seem central to successful communication and it would follow that they should be a major part of teaching syllabuses, whether general or specialised. For this reason, the OPAL academic word lists provide both single- and multi-word lists as a useful resource for teachers, students and materials writers. While many chunks have long been included in language teaching materials, others are often either dismissed as 'fillers' or meaningless strings (e.g. I mean, you know: see the discussion in Fox Tree \& Schrock 2002) or neglected. Examples of neglect are the vague category makers such as or something, and things like that (see below), items which only came to prominence as target expressions in teaching materials in the early 2000s with the publication of McCarthy, McCarten and Sandiford (2005a, 2005b, 2006a, 2006b).

17 The importance of chunks as central to communication has been one of the major developments in our understanding of discourse, including social conversation and 
academic speaking. Erman and Warren (2000), for example, estimate that chunks constitute some fifty-five percent of an average given text, with conversational texts having a higher percentage. Hopper shows how most of a conversational transcript can be accounted for by groups of words which return hits from an internet search engine ranging from hundreds to millions. Informal dialogue, says Hopper, consists of 'the linear on-line assembly of familiar fragments' (Hopper 2011: 26). Sinclair (1991, 2003, 2004) refers to the ubiquity of chunks as the 'idiom principle': a great deal of language comes ready-made, like off-the-peg garments rather than tailor-made on every different occasion. This has implications for the notion of spoken fluency, which chunks facilitate, to the extent that speaking fluently would hardly be possible if one had to create every individual word of every utterance afresh on every occasion of use (McCarthy 2010). It also has implications for the traditional division of grammar versus lexis: chunks, because they are fixed in form, have no internal grammar, which leads to the conclusion that the concept of lexico-grammar, where grammar and lexis complement each other, may be more useful in spoken language pedagogy than the traditional grammar/lexis split when fluency is the target (see Willis 2003 for a general discussion; see also Schulze and Römer 2010: 5). In academic contexts, speaking fluently is not only a significant realisation of interactional competence, it is also key to full participation in the learning process, it facilitates social integration in the academic community and it reduces problems associated with cultural adaptation for those studying through a second or foreign language medium (Yeh \& Inose 2003).

A major category of chunks that falls into the strategic area of projecting assumed shared knowledge (a key element in academic teaching and learning, where new knowledge most successfully integrates with existing knowledge) is vague category markers (VCMs). Vague category marking happens through the exploitation of a repertoire of lexico-grammatical chunks which project categories that the speaker assumes the listener will be able to interpret without the need to give an exhaustive list of possible items in the category. Such markers may evoke established, more permanent lexical categories or, equally, categories adequate for the immediate context (Overstreet 1999: 12, Overstreet 2014). As such, they take interlocutors into a "shared social space" (Evison, McCarthy and O'Keeffe 2007). Common examples of VCMs in everyday, social conversation include or something and and stuff (like that) and and things (like that). Speakers typically use these after one, sometimes two examples of a topic or category, the exemplar(s), to refer to other items in that category, where to list every example of what is included would be odd, overly explicit and drastically uneconomical. The following slightly edited ${ }^{1}$ example from a family conversation in CANCODE about a campsite includes two such VCMs, and things like that and and everything like that, to refer to the various facilities that the campsite offers.

\section{Example 1}

$<$ spkr2F> Do they have restaurants and things like that?

$<s p k r 3 F>$ Oh yeah. They have shops and restaurants and like MacDonalds and pizza +

$<$ spkr2F> Mm.

$<$ spkr3F> + places. And +

$<$ spkr4M> Right.

$<$ spkr3F> + everything like that 
that others will recognise what else might be understood and listeners rarely if ever challenge or question what is being referred to. This promotion of a shared world view can be strategic in different contexts. Koester (2006:91) in studying the workplace found that such vague language created "a sense of familiarity and common ground" and that it was absent in conflict situations. Handford (2010:164), in a study of business English, suggests their increased use in inter-company as opposed to internal business meetings can be tactical to promote a sense of bonding in business negotiations. O'Keeffe (2006) cites their use as one of several linguistic means of reinforcing national and cultural identity. The ubiquity and function of VCMs as contributing to successful interactional exchanges in different contexts is also described among others by Channell (1994), Cutting (2007), Pichler and Levey (2010), Sabet and Zhang (2015) and Vaughan et al. (2017).

VCMs also occur widely in spoken academic English. In BASE and so on is the sixth most frequent three-word chunk and the top two six-word chunks are and so on and so forth, and all the rest of it. Their use does include the general conversational use as exemplified above, i.e. referring to concepts that anyone might understand, but they are also widely used to project an assumption of shared disciplinary knowledge of a specialised nature. In this example from an immunology lecture in the academic sub-corpus of CANCODE, the lecturer assumes that students know enough about cell structure to understand the point being made.

\section{Example 2}

They become bigger cells because they develop more cytoplasm and more er like mitochondria and $e=$ endoplasmic reticulum and so on so they become metabolically active cells and start to divide

21 Put crudely, any student who does not know more or less what the projected category which and so on encodes in this context is potentially in trouble and may feel excluded from particular elements of knowledge and the immediate discourse. Participating in vague category marking, whether as speaker or listener(s) is an aspect of interactional competence, and the use of VCMs can be seen as a significant aspect of the management of academic interaction; it is a shorthand for what students should already know.

Chunks develop specialised pragmatic uses in particular discourse environments (Schulze and Römer 2010). An example in the context of academic English is the chunk in terms of, which occurs 142 times in the CANCODE spoken academic sub-corpus, equalling a normalised total of 308 occurrences per million words. In the one-millionword social conversation sub-corpus of CANCODE, in terms of occurs a mere 44 times. Why such a great difference? The answer lies in the function of in terms of, which enables topics, items of knowledge, ideas, etc. to be related to or to be explicated through one another, thus building knowledge both horizontally and vertically, enabling new knowledge to be grafted on to existing knowledge. These are all fundamental features of academic discourse and, in the case of academic speaking, basic strategies in the management of interaction. Another chunk which operates in a similar way in academic speaking is in the sense that, which is five times more frequent in academic contexts than in social conversation.

\section{Keyword lists}


Keyword lists are typically derived from a statistical comparison of items in one corpus with another, for example a specialised spoken corpus with a more general corpus or a corpus of academic talk with a corpus of academic writing. Keyword analysis identifies those items, single words, lemmas, or chunks, which occur with statistical significance more (or less) frequently in the corpus of interest than in the other, typically larger, benchmark corpus. Keyword lists provide complementary information to raw frequency lists in that they identify the items that are particularly common (or rare) in the genre under investigation and which can be said to constitute its characteristic nature, its fingerprint or 'DNA'.

One of the most interesting features of the key lemma list for our spoken academic data when it is measured against the benchmark of the BNCB written academic sub-corpus is that it contains many items that are very frequent in social conversation and which would occur in a keyword list comparing general conversation with general written data. Earlier, we mentioned that $I$ and you had reversed their typical conversational rank-ordering to you and $I$ in the BASE corpus. This is shown even more strongly in the spoken academic keyword list, where you ranks at number one and I at number four, with you more than one and a half times more frequent than $I$. This illustrates the directionality of academic discourse: it is tutors overwhelmingly who address students in the second person, rather than the more balanced to and fro of 'me and you' in social conversation.

Despite an expectation that academic discourse might be more formal in nature than social conversation - and it often is - the response tokens yeah (as opposed to yes) and okay rank in the top 20 key lemmas. Okay also functions as a discourse marker and is joined by well, right and so, which are among the most common markers in general conversation (Schiffrin 1987, Watts 1989). Also present in the list as well as in conversation are the lexical verbs know and think and mean because of the chunks you know, I think and I mean, which frame utterances expressing states of shared and nonshared knowledge. Evidence of hedging can also be found in the prevalence of think, along with sort (sort of) and just; sort also commonly forms part of the VCM that sort of thing, which occurs 14 times in the academic sub-corpus of CANCODE. Finally, for the purposes of this article, further down the list, but still occurring with high statistical significance, we find the adverbs actually, really, maybe, basically and obviously, which again are equally at home in the frequency lists of social conversation data and some of which, research suggests, may be distributed differently in native- and non-native speaker use (Pérez-Paredes \& Camino Bueno-Alastuey 2019).

\section{Using coded speaker information}

If spoken corpus data is well-annotated and contains codes indicating points of speaker change, one can do more than generate frequency lists for the whole body of data. Most usefully, one can investigate what occurs at points of speaker change, especially any patterns of lexico-grammar which recur at the start of speaker turns. Tao (2003) points to turn beginnings as being particularly important as indicators of interaction management. Tao's argument reflects Sacks et al.'s (1974) labelling of the three major internal components of a turn, with a first part which "addresses the relation of the turn to a prior" (p. 36). Tao (2003) demonstrated that turn-opening items in English conversation are typically lexical in nature and are generally syntactically freestanding. Items which are of high frequency in the language as a whole, such as the definite article, are notable by their infrequency at the start of speaker turns (see also 
Evison 2013a and b, whose spoken academic data revealed a similar pattern). The turninitial slot is populated by items such as yes, well, right, okay and pronouns in fixed expressions such as I think, you know, I mean, that's + adjective (that's right, that's true), etc. The turn-initial position is one where speakers select items which manifest both interpersonal engagement and goal-orientation. Tao asserts that speakers attend to the interactional context and the prior speaking turn(s) before making content-oriented, transactional contributions. This is particularly important when considering academic contexts where the dual elements of goal-orientation towards the transmission, fostering and sharing of academic knowledge is accompanied by the equally important goal of fostering and maintaining good tutor-student relations. The turn-opening may be said to be a key locus for interactional management, the place where engaged listenership most clearly manifests itself. It is also the real-time moment where choices are made in the ordering and functioning of sequences of items such as discourse markers which bracket or manage the subsequent talk (Haselow 2019).

As with all frequency lists, whether for a whole dataset or just for turn-openers, the picture is not quite so simple, because is not enough just to know what forms occur with significant frequency; what is equally important is the distribution of those forms among speakers. Who uses them, when and what for? Evison (2013a) looked at more than 13,000 turn-openings in academic discourse and found many examples of seemingly conversational discourse markers such as okay and all right. However, she argues that simply looking at items in a specialised corpus (e.g. in a raw frequency list) misses the significance of item position and distribution across speakers. She shows that, although items occurring at turn-initial position largely correspond to those found in everyday conversation, lecturers and tutors regularly open their turns with items that students far less frequently have access to (e.g. okay, all right). This reflects who is typically most in control of the discourse in an academic institutional setting. How turns open and proceed relates to the epistemological, pedagogical and institutional contexts of academic discourse and the discourse roles to which participants orientate. Academic events are goal-driven and time-governed. There is no time for the topical meanderings of social conversation. The academic conversation, like the radio phone-in discourse referred to in the introduction to this article, is a pseudo-conversation; it functions efficiently to bond the participants and to create good relations and a positive atmosphere, but in the final analysis, it has an agenda to get through and goals to reach before the bell rings.

\section{Helping students to get used to academic speaking}

Many of the conversational items present in our data occur across all the academic spoken genres, from lectures to seminars and one-to-one encounters. There are, of course, exceptional cases which exclude the use of certain features: the audience in a lecture are not expected to respond verbally with response tokens such as Really? Okay or Wow! However, the central insight we take from the corpus evidence is that, if students have a good grounding in conversational interaction and the language and strategies employed to organise their talk and the conversation as a whole with discourse markers, to take account of others by hedging their talk and using vague category markers to project commonality and so on, they will have a firm basis on which to go on to participate actively and successfully in academic interaction. 
31

ights into language use from corpus research can be incorporated into materials to help students to learn the conventions of spoken academic discourse and the interaction management strategies they will be exposed to (at the hands of their tutors and peers) and which, at different points in their academic programmes (oral presentations, pair- and group-work, advisory sessions and supervisions) they will have need of for their own use. A starting point is to build a syllabus of such features. McCarthy and McCarten $(2010,2012)$ propose a model of conversational behaviour falling into four categories of (a) organising your own talk, (b) taking account of other speakers, (c) listenership and (d) organising the conversation as a whole. As noted in our introduction, the model can be adapted to academic discourse as (a) organising one's own contribution and the discourse as a whole, (b) taking account of the listener(s)/participant(s), (c) engaged listenership and (d) transmitting, fostering, displaying and sharing of academic knowledge.

Items which might in a general conversation syllabus belong to one category in social conversation may also in academic discourse belong to the last category of imparting academic knowledge. One example is the chunk I don't know plus if, when, what etc., used in conversation to hedge the imparting of information by exploring what is known by the listener and often interpreted as an interrogative (Biber 2009, Grant 2010), especially when followed by you, as in the following example from CANCODE:

\section{Example 3}

$<$ spkr1> Er I don't know if you heard read about the young girl last year that was

$<$ spkr2> Yes.

$<$ spkr1> refused treatment.

$<$ spkr3> Yeah that was terrible.

In academic teaching contexts I don't know if you is typically used by teachers as a checking mechanism to see if students understand a term or concept before they go on to explain it. It is rarely if ever used as an admission of ignorance (see also the discussion of its French equivalent, je sais pas, in Pekarek Doehler 2016). In the following examples from linguistics and philosophy seminars in MICASE, the senior faculty member uses the I don't know if you pattern in the information checking function. The teacher then follows up by asking more explicitly signalled questions (inflection? have you heard of it?), in one case directed at an individual student, before going on to explain the concept. Thus, the tutor exploits a common conversational device of exploring shared knowledge as a prelude to the goal of imparting/sharing new knowledge.

\section{Example 4}

[...] it is agreed that mixing seems not to occur between constituents that are contained, in the INFL phrase. Um, i don't know if you know what the INFL phrase is. inflection? um it's for instance um well, in a verb, we have inflections $m$ - the ending of the verbs, [...]

\section{Example 5}

um, $\boldsymbol{i}$ don't know if you've heard of the, the last man, and this uh this uh very postmodernist notion, which Foucault mentions and Derrida also mentions have you heard of it, do you know what that is? do you know Sung what the last man is? uh, (an explanation of the term follows) 
methodology, McCarthy and McCarten (2018) offer a set of principles for the teaching and practice of social conversation, principles which, again with only light adaptation can easily be applied to an academic setting. These principles sit within the wider framework of the 'three Is' approach as formulated by Carter and McCarthy (1995), the Is standing for: Illustration, i.e. the exemplification of a language item in a corpus-derived context; Interaction, which refers to interaction with the text exemplifying the language feature, usually through active noticing, finding more examples of the feature, and finally Induction, whereby students incorporate their newly-acquired knowledge in active practice and personalised use.

teaching strategic spoken language items (whether in general conversation or academic spoken language) it is important that students work with a spoken text which is representative of what they aspire to produce themselves. These texts can be drawn from actual corpus examples, although these frequently need to be edited, as spoken transcripts often contain contextual elements which the transcribers have annotated (e.g. a dog barking in the background, a cough) or false starts and aborted or fragmented utterances which may be of interest to conversation analysts but which are often distracting or off-putting to learners, based on our own teaching experience (see McCarten 2010 for a more extended discussion of editing). We would also support Delahaie's (2013) suggestion in relation to the teaching of French to use 'une reconstruction idéale du dialogue authentique' or naturalistic representations of authentic language, as actual corpus examples can be difficult to use. Conversation-analytical discussions of narrowly transcribed talk in applied linguistics settings are one thing; practical, time-constrained speaking skills lessons for second language learners are another, and any assistance the materials writer can provide through a moderate degree of 'reconstruction' is to be welcomed. For example, Carter and McCarthy (1997) offer re-recorded extracts from the CANCODE corpus using professional actors alongside the original recordings, another form of idealisation. In our approach as materials writers, students first become familiar with the meaning of the text, both in terms of language and ideas, so that comprehension is no problem, before looking at how speakers encode organisational and interactional meanings. Noticing and language awareness as methodological principles have long been recognised as key elements in successful language learning (Schmidt 1990, 1993, Van Lier 1998, Clennell 1999, Hughes 2002, O'Keeffe and Farr 2003) and students need access to the transcript or its adapted form (most typically as printouts or included in the course book or online) to enable them to notice patterns or find further examples of the target language items, such as chunks, discourse markers and response items, rather than simply having them served up as a list. Awareness is also important in relation to differences between academic speaking and writing, with some evidence that L2 learners of English may use spoken discourse markers typically associated with speaking inappropriately in their writing (Pınar Babanoğlu 2014). Armed with awareness and good practice, available lists such as the OPAL lists then become a resource of functions and the items which realise them that the student user is already familiar with.

It is worth mentioning here a study by Golebiewska and Jones (2018) in an English for Academic Purposes (EAP) setting, where the language focus was a set of 12 interactional spoken chunks. They compared two methodological approaches: Present Practise Produce (PPP), which emphasises active production, and Lewis' (1997) Observe Hypothesize Experiment (OHE), which is understood to prioritise noticing and 
'receptive practice'. Although their sample was small, they found that OHE had a slight advantage in students' productive knowledge. Thus, they advocate that teachers exploit a wide range of methodology types in teaching lexis of this type.

As noted above, McCarthy and McCarten (2018) offer principles for spoken practice to lead to successful induction of new items. We will not repeat them all here, but simply mention one, which is that the vehicles for practice (e.g. 'sentence-length' utterances, presentation extracts, exchanges) should be both representative of the discourse type in question and supportive in that students may easily perceive how they might use or adapt them for their own utterances and successful participation in exchanges. In this way it is hoped that students may be able both to 'authenticate' the language (Widdowson 1998), that is to perceive it themselves as authentic and to use it authentically, i.e. in a manner that others will hear as 'unremarkable' in the sense of being natural, fluent and meeting academic expectations. Examples of the teaching and practice of interactional chunks can be found the Lesson C sections of McCarthy, McCarten and Sandiford $(2012,2014)$, which include exchanges in a range of contexts, including academic settings. We also acknowledge here the corpus research and practical pedagogical activities related to the oral demands of French for academic purposes (FOU) and for specific purposes (FOS) by researchers such as Mangiante and Parpette (2011) and Dufour and Parpette (2018).

\section{Conclusion}

Academic speaking shares much with everyday interaction but has its own characteristics which relate to the goal-driven nature of institutional talk and the display, transmission and sharing of knowledge. Students need not only to learn how to write academically but how to engage in the different types of interaction which make up a college/university experience. Our firm belief, backed up by corpus evidence, is that a focus on interactional competence in general language classes and training in basic, social conversational strategies provide an excellent foundation for what students will experience in spoken academic events.

At the beginning of this article, we mentioned that academic institutions label, for timetabling purposes, different types of academic encounter, such as lecture, seminar, supervision, office-hour. From the point of view of participant roles, these clearly make different demands on students. In a formal lecture, students are expected to listen but not verbally respond. In a solo oral presentation, the student is in a similar position to the institutional lecturer. In an office-hour or one-to-one advisory session, the student also has a more active role, which will sometimes demand skills of topic management and verbal response, as well as engaged listenership on the part of both participants (Farr 2003). In pair- and group-work, students must also show engaged listenership and not just passively receive information or sit on the sidelines: one of their interactional obligations will be to attend to what the previous speaker has just said before embarking on what they want to say, creating turn-configurations akin to those of social conversation while keeping on message in terms of the academic agenda. What is most notable in all this variety of types of interaction is the degree of overlap that can be observed in the different types of events recorded in the corpora. VCMs, for instance, occur in every type of interaction, from the monologue lecture to supervision sessions, to the more informal atmosphere of pair- and group-work, while engaged 
listenership and fluent response will be equally important in tasks carried out with fellow-students as in the office-hour advisory session or in a Q \& A session after a presentation. Discourse marking will be important in all the different types of encounter, since academic discourse cannot just ramble aimlessly and must pursue its epistemological and pedagogic goals relentlessly and in an organised fashion, even if that organisation is subliminally mediated through pseudo-conversational strategies. The corpus evidence is available and accessible, but it is understanding and drilling down into the data which is essential rather than relying on raw figures and, above all, having a grounded methodology for exploiting such data when assisting students who will study or are studying through a foreign or second language.

Since no pre-sessional or in-sessional programme in a field such as English for Academic Purposes (EAP) can hope to cover in depth all types of academic interaction and every possible discourse role that students will find themselves in, the best course of action is to raise awareness of and train and practise the conversational strategies that underlie interactional competence both in daily life and in more specialised areas. Most students, when they have concluded their academic studies, will pursue professional or vocational pathways or go on to further academic studies, and the more successful they are in exploiting the key features of interactional competence, the more successful they are likely to be in following those pathways, achieving their academic goals and ultimately becoming integrated into the communities of their chosen professions.

\section{BIBLIOGRAPHY}

ADOLPHS, S., SCHMITT, N., 2003, « Lexical Coverage of Spoken Discourse », Applied Linguistics, 24 (4), p. 425-438.

ADOLPHS, S., SCHMITT, N., 2004, « Vocabulary coverage according to spoken discourse Context ", dans P. Bogaards, B. Laufer (éds) Vocabulary in a second language, Amsterdam : John Benjamins, p. 39-49.

ATKINSON, J. M., HERITAGE, J. (éds), 1984, Structures of Social Action: Studies in Conversation Analysis, Cambridge: Cambridge University Press.

BAMFORD, J., 2005, « Subjective or objective evaluation? Prediction in academic lectures », dans E. Tognini-Bonelli, G. Del Lungo Camiciotti (éds), Strategies in Academic Discourse, Amsterdam: John Benjamins, p. 17-29.

BEECHING, K., 2016, Pragmatic Markers in British English, Cambridge: Cambridge University Press.

BENWELL, B., STOKOE, E. H., 2002, «The construction of discussion tasks in university tutorials », Discourse Studies, 4 (4), p. 429-453.

BHATIA, V. K., 2002, « A generic view of academic discourse », dans J. Flowerdew (éd.) Academic Discourse, London: Pearson Education, p. 21-39. 
BIBER, D., 2006, University language: A corpus-based study of spoken and written registers, Amsterdam: John Benjamins.

BIBER, D., 2009, « A corpus-driven approach to formulaic language: Multi-word patterns in speech and writing », International Journal of Corpus Linguistics 14 (38), p. 1-417.

BIBER, D., JOHANSSON, S., LEECH, G., CONRAD, S., FINEGAN, E., 1999, Longman Grammar of Spoken and Written English, London: Longman.

BUTTERY, P., MCCARTHY, M. J., CARTER, R. A., 2015, « Chatting in the academy: informality in spoken academic discourse ", dans N. Groom, M. Charles \& S. John (eds) Corpora, Grammar and Discourse. In honour of Susan Hunston, Amsterdam: John Benjamins, p. 183-210.

CARTER, R., MCCARTHY, M. J., 1995, « Grammar and the spoken language », Applied Linguistics 16 (2), p. 141-158.

CARTER, R. A., MCCARTHY, M. J., 1997, Exploring Spoken English, Cambridge: Cambridge University Press.

CARTER, R. A., MCCARTHY, M. J., 2006, Cambridge Grammar of English. Cambridge: Cambridge University Press.

CHANNELL, J., 1994, Vague language, Oxford: Oxford University Press.

CHAUDRON, C., RICHARDS, J. C., 1986, « The Effect of Discourse Markers on the Comprehension of Lectures », Applied Linguistics 7 (2), p. 113-127.

CLENNELL, C., 1999, « Promoting pragmatic awareness and spoken discourse skills within EAP classes », ELT Journal 53, p. 83-91.

COULTHARD, R. M., MONTGOMERY, M., 1981, « The structure of monologue », dans R. M. Coulthard \& M. Montgomery (eds) Studies in Discourse Analysis, London: Routledge \& Keagan Paul, p. 31-39.

CSOMAY, E., 2007, « A corpus-based look at linguistic variation in classroom interaction: Teacher talk versus student talk in American university classes ", Journal of English for Academic Purposes 6 (4), p. 336-355.

CUTTING, J. (éd), 2007, Vague language explored, Basingstoke: Palgrave Macmillan.

DANG, T. N. Y., Webb, S., 2014, « The lexical profile of academic spoken English », English for Specific Purposes 33, p. 66-76.

DELAHAIE, J., 2013, « Constitution et exploitation de corpus d'interactions verbales pour le FLE : problèmes et programme ", Linx [En ligne], p. 68-69, mis en ligne le 19 décembre 2015, consulté le 20 juillet 2019. URL : http://journals.openedition.org/linx/1498.

DREW, P., HERITAGE, J. (eds), 1992, Talk at Work: Interaction in institutional settings, Cambridge: Cambridge University Press.

DUFOUR, S., PARPETTE, C., 2018, « Le français sur objectif spécifique : la notion d'authentique revisitée ", ILCEA [En ligne], 32 consulté le 21 janvier 2020. URL : http:// journals.openedition.org/ilcea/4814.

ERMAN, B., WARREN, B., 2000, « The idiom principle and the open choice principle » Text 20 (1), p. 29-62.

EVISON, J., 2013a, « A corpus linguistic analysis of turn-openings in spoken academic discourse: Understanding discursive specialisation », English Profile Journal 3, E4. 
EVISON, J., 2013b, « Turn openings in academic talk: where goals and roles intersect », Classroom Discourse 4 (1), p. 3-26.

EVISON, J., MCCARTHY, M. J., O'KEEFFE, A., 2007, « Looking out for love and all the rest of it: Vague category markers as shared social space », dans J. Cutting (ed.) Vague Language Explored, Basingstoke: Palgrave Macmillan, p.138-157.

FARR, F., 2003, « Engaged listenership in spoken academic discourse: The case of student-tutor meetings », Journal of English for Academic Purposes 2 (1), p. 67-85.

FAIRCLOUGH, N., 1994, « Conversationalization of public discourse and the authority of the consumer », dans R. Keat, N. Whiteley \& N. Abercrombie (eds), The Authority of the Consumer, Abingdon, Oxon: Routledge, p. 253-268.

FORTANET, I., 2004, " The use of 'we' in university lectures: reference and function ", English for Specific Purposes 23 (1) p. 45-66.

FOX TREE, J. E., SCHROCK, J. C., 2002, « Basic meanings of you know and I mean », Journal of Pragmatics 34, p. 727-747.

GOFFMAN, E., 1981, Forms of talk. Oxford: Basil Blackwell.

GOLEBIEWSKA, P., JONES, C., 2018, « The Teaching and Learning of Lexical Chunks: A Comparison of Receptive and Productive Practice », dans C. Jones (ed.) Practice in Second Language Learning, Cambridge: Cambridge University Press.

GRANT, L., 2010, « A corpus comparison of the use of I don't know by British and New Zealand speakers », Journal of Pragmatics 42, p. 2282-2296.

GUILLOT, M-N., 2002, « Corpus-based work and discourse analysis in FL pedagogy: a reassessment ", System 30 (1), p. 15-32.

HANDFORD, M., 2010, The Language of Business Meetings, Cambridge: Cambridge University Press.

HASELOW, A., 2019, « Discourse marker sequences: Insights into the serial order of communicative tasks in real-time turn production ", Journal of Pragmatics 146, p. 1-18.

HOPPER, P., 2011, « Emergent grammar and temporality in interactional linguistics », dans P. Auer \& S. Pfänder (eds) Constructions: Emerging and Emergent, Berlin : Walter de Gruyter, p. 22-44.

HUGHES, R., 2002, Teaching and Researching Speaking, Harlow: Pearson Education.

KOESTER, A., 2006, Investigating Workplace Discourse, Abingdon: Routledge.

HUTCHBY, I., WOOFFITT, R., 1988, Conversation Analysis, Cambridge: Polity Press.

LEE, J. J., SUBTIRELU, N. C., 2015, « Metadiscourse in the classroom: A comparative analysis of EAP lessons and university lectures ", English for Specific Purposes 37, p. 52-62.

LEWIS, M., 1997, Implementing the Lexical Approach: Putting Theory into Practice, Hove: Language Teaching Publications.

MANGIANTE, J-M., PARPETTE, C., 2011, Le français sur objectif universitaire, Grenoble: Presse universitaires de Grenoble.

MAURANEN, A., 2004, « Speech corpora in the classroom », dans G. Aston, S. Bernardini, D. Stewart (eds) Corpora and language learners, Amsterdam: John Benjamins, p. 195-211.

MCCARTEN, J., 2010, « Corpus-informed course book design », dans A. O'Keeffe \& M. J. McCarthy (eds) The Routledge Handbook of Corpus Linguistics, Oxford: Routledge, p. 413-442. 
MCCARTEN, J., MCCARTHY, M. J., 2010, « Bridging the gap between corpus and course book: the case of conversation strategies ", dans F. Mishan \& A. Chambers (eds) Perspectives on Language Learning Materials Development, Oxford: Peter Lang, p. 11-32.

MCCARTHY, M. J., 1998, Spoken Language and Applied Linguistics, Cambridge: Cambridge University Press.

MCCARTHY, M. J., 2002, « Good listenership made plain: British and American non-minimal response tokens in everyday conversation ", dans R. Reppen, S. Fitzmaurice \& D. Biber (eds) Using corpora to explore linguistic variation, Amsterdam: John Benjamins, p. 49-71.

MCCARTHY, M. J., 2003, « Talking back: 'small' interactional response tokens in everyday conversation », Research on Language in Social Interaction 36 (1), p. 33-63.

MCCARTHY, M. J., 2010, « Spoken fluency revisited », English Profile Journal, 1, E4.

MCCARTHY, M. J., MCCARTEN, J., 2012, « Corpora and materials design », dans K. L. Hyland, M. H. Chau \& M. Handford (eds) Corpus Applications in Applied Linguistics, London \& New York: Continuum, p. 225-241.

MCCARTHY, M. J., MCCARTEN, J., 2018, « Now you're talking! Practising Conversation in Second Language Learning », dans C. Jones (ed.) Practice in Second Language Learning, Cambridge: Cambridge University Press.

MCCARTHY, M. J., MCCARTEN, J., Sandiford, H., 2005a, Touchstone Student's Book 1, Cambridge: Cambridge University Press.

MCCARTHY, M. J., MCCARTEN, J., Sandiford, H., 2005b, Touchstone Student's Book 2, Cambridge: Cambridge University Press.

MCCARTHY, M. J., MCCARTEN, J., Sandiford, H., 2006a, Touchstone Student's Book 3, Cambridge: Cambridge University Press.

MCCARTHY, M. J., MCCARTEN, J., Sandiford, H., 2006b, Touchstone Student's Book 4. Cambridge: Cambridge University Press.

MCCARTHY, M. J., MCCARTEN, J., Sandiford, H., 2012, Viewpoint Student's Book 1, Cambridge: Cambridge University Press.

MCCARTHY, M. J., MCCARTEN, J., Sandiford, H., 2014, Viewpoint Student's Book 2, Cambridge: Cambridge University Press.

NATTINGER, J., DECARRICO, J., 1992, Lexical Phrases and Language Teaching, Oxford: Oxford University Press.

NESI, H., BASTURKMEN, H., 2006, « Lexical bundles and discourse signalling in academic lectures », International Journal of Corpus Linguistics 11 (3), p. 283-304.

O'KEEFFE, A., 2006, Investigating media discourse, London: Routledge.

O'KEEFFE, A., FARR, F., 2003, « Using Language Corpora in Language Teacher Education: pedagogic, linguistic and cultural insights », TESOL Quarterly 37, p. 389-418.

O’KEEFFE, A., MCCARTHY, M.J., CARTER, R.A., 2007, From Corpus to Classroom, Cambridge: Cambridge University Press.

OVERSTREET, M., 1999, Whales, candlelight and stuff like that: General extenders in English discourse, New York: Oxford University Press. 
OVERSTREET, M., 2014, « The role of pragmatic function in the grammaticalization of English general extenders », Pragmatics 24 (1), p. 105-129.

PEKAREK DOEHLER, S., 2016, « More than an epistemic hedge: French je sais pas 'I don't know' as a resource for the sequential organization of turns and actions », Journal of Pragmatics 106,

p. 148-162.

PEKAREK DOEHLER, S., 2018, « Elaborations on L2 interactional competence: the development of L2 grammar-for-interaction », Classroom Discourse 9 (1), p. 3-24.

PÉREZ-PAREDES, P., CAMINO BUENO-ALASTUEY, M., 2019, « A corpus-driven analysis of certainty stance adverbs: Obviously, really and actually in spoken native and learner English », Journal of Pragmatics 140, p. 22-32.

PICHLER, H., LEVEY, S., 2010, « Variability in the co-occurrence of discourse features », University of Reading Language Studies Working Papers 2, p. 17-27.

PINAR BABANOĞLU, M., 2014, « A corpus-based study on the use of pragmatic markers as speechlike features in Turkish EFL learners' argumentative essays », Procedia-Social and Behavioral Sciences 136, p. 186-193.

POOS, D., SIMPSON, R. C., 2002, « Cross-disciplinary comparisons of hedging: Some findings from the Michigan Corpus of Academic Spoken English », dans R. Reppen, S. Fitzmaurice \& D. Biber (eds) Using corpora to explore linguistic variation, New York: John Benjamins, p. 3-23.

RENDLE-SHORT, J., 2016, The Academic Presentation: Situated Talk in Action, Abingdon, Oxon: Routledge.

RÜHLEMANN, C., 2007, Conversation in Context. A Corpus-Driven Approach. London: Continuum. SABET, p. G. P., ZHANG, G. Q., 2015, Communicating Through Vague Language: A Comparative Study of L1 and L2 Speakers, Basingstoke: Palgrave Macmillan.

SACKS, H., SCHEGLOFF, E., JEFFERSON, G., 1974, « A simplest systematics for the organization of turn-taking for conversation », Language 50, p. 696-735.

SCHMIDT, R., 1990, « The role of consciousness in second language learning », Applied Linguistics 11, p.129-158.

SCHMIDT, R., 1993, « Awareness and second language acquisition », Annual Review of Applied Linguistics 13, p. 206-226.

SCHIFFRIN, D., 1987, Discourse Markers, Cambridge: Cambridge University Press.

SCHMITT, N. (ed.), 2004, Formulaic Sequences, Amsterdam: John Benjamins.

SCHMITT, N., COBB, T., HORST, M., SCHMITT, D., 2017, « How much vocabulary is needed to use English? Replication of van Zeeland \& Schmitt (2012), Nation (2006) and Cobb (2007) ", Language Teaching 50 (2), p. 212-226.

SCHULZE, R., RÖMER, U., 2010, « Introduction », dans U. Römer \& R. Schulze (eds) Patterns, Meaningful Units and Specialized Discourses, Amsterdam: John Benjamins, p. 1-6.

SINCLAIR, J. McH., 1991, Corpus, concordance, collocation, Oxford: Oxford University Press.

SINCLAIR, J. McH., 2003, Reading Concordances, Harlow: Longman.

SINCLAIR, J. McH. (éd.), 2004, How to use Corpora in Language Teaching, Amsterdam and Philadelphia, PA: John Benjamins.

STENSTRÖM, A.-B., 1994, An introduction to spoken interaction, London: Longman. 
STRODT-LOPEZ, B., 1991, « Tying it all in: Asides in university lectures », Applied Linguistics 12 (2), p. $117-140$.

SWALES, J. M., Malczewski, B., 2001, « Discourse management and new episode flags in MICASE », dans R. C. Simpson \& J. M. Swales (eds) Corpus linguistics in North America: Selections from the 1999 symposium, Michigan: University of Michigan, p. 145-164.

TAO, H., 2003, « Turn initiators in spoken English, a corpus-based approach to interaction and grammar ", dans C. Meyer \& P. Leistyna (eds) Corpus analysis, language structure and language use, Amsterdam: Rodopi, p. 187-207.

THOMPSON, S. E., 2003, « Text-structuring metadiscourse, intonation and the signalling of organisation in academic lectures », Journal of English for Academic Purposes 2 (1), p. 5-20.

VAN LIER, L., 1998, « The relationship between consciousness, interaction and language learning », Language Awareness 7, p. 128-145.

VAUGHAN, E., MCCARTHY, M. J., CLANCY, B., 2017, « Vague category markers as turn-final items in Irish English », World Englishes 36 (2), p. 208-223.

WATTS, R. J., 1989, « Taking the pitcher to the "well”: native speakers' perception of their use of discourse markers in conversation ", Journal of Pragmatics 13, p. 203-37.

WIDDOWSON, H. G., 1998, « Context, community, and authentic language », TESOL Quarterly 32 (4), p. 705-16.

WILLIS, D., 2003, Rules, Patterns and Words. Grammar and Lexis in English Language Teaching, Cambridge: Cambridge University Press.

WRAY, A., 2000, « Formulaic sequences in second language teaching: principle and practice », Applied Linguistics 21, p. 463-489.

YEH, C. J., INOSE, M., 2003, « International students' reported English fluency, social support satisfaction, and social connectedness as predictors of acculturative stress ", Counselling Psychology Quarterly 16 (1), p. 15-28.

YOUNG, L., 1994, « University lectures: Macro-structure and micro-features », dans J. Flowerdew (ed.), Academic Listening: Research Perspectives, Cambridge: Cambridge University Press, p. 159-176. YOUNG, R. F., 2013, « Learning to talk the talk and walk the walk: Interactional competence in academic spoken English », Ibérica 25, p. 15-38. Available online at http://www.redalyc.org/ articulo.oa?id=287026237002.

\section{NOTES}

1. In this case, the editing of the transcript involved removing an annotation indicating <spkr3F> clearing her throat, which is irrelevant to the present discussion. 


\section{ABSTRACTS}

In this article we look at some basic features of interaction and compare their occurrence and functions in everyday English conversation with their use in academic speaking. The features include discourse markers, vague category markers, response tokens and interpersonal chunks. We give examples from spoken corpora and illustrate the special functions of the features in academic interactions. We then consider issues in the teaching of spoken academic English and fostering awareness of academic interactions to underpin practice in and reinforcement of the most common features of interactional management in academic English which students are likely to encounter.

Dans cet article, nous étudions quelques caractéristiques de base de l'interaction et comparons leurs réalisations et leurs fonctions en anglais usuel avec celles de l'anglais académique. Les caractéristiques observées incluent les marqueurs du discours, les marqueurs de catégories vagues, les retours minimaux et les blocs lexicaux interpersonnels. Nous offrons des exemples de corpus oraux et illustrons les fonctions spécifiques des interactions universitaires. Puis, nous nous intéressons à l'enseignement de cet anglais oral académique : la prise de conscience des spécificités de ces interactions permet d'étayer l'utilité pédagogique de la pratique et du renforcement des caractéristiques les plus communes de la gestion des interactions de ce type, que les étudiants vont probablement rencontrer.

\section{INDEX}

Mots-clés: langue académique, corpus oraux, marqueurs du discours, blocs lexicaux, vague Keywords: academic language, spoken corpora, discourse markers, chunks, vague language

\section{AUTHORS}

\section{MICHAEL MCCARTHY}

Professeur émérite, University of Nottingham, UK

\section{JEANNE MCCARTEN}

Auteure freelance et consultante anglais langue étrangère 